\title{
SAMUEL JOHNSON'S ALCOHOL PROBLEM
}

\author{
by
}

\section{J. S. MADDEN}

THERE is ample evidence to show that Samuel Johnson's ability to moderate his consumption of alcohol was so impaired that for long periods he was obliged to abstain. Hannah More described how, when she urged him 'to take a little wine, he replied, "I can't drink a little, child, therefore I never touch it. Abstinence is as easy to me, as temperance would be difficult." '1 When he was on Skye, Lady M'Leod, hardly crediting his reason for refusing drink, said, 'I am sure, sir, you would not carry it too far,' to which Johnson replied, 'Nay, madam, it carried me. I took the opportunity of a long illness to leave it off. It was then prescribed to me not to drink wine; and having broken off the habit, I have never returned to it.'2 Mrs. Thrale noted: 'With regard to.Drink his liking is for the strongest [her italics], as it is not the Flavour but the Effect of Wine which he even professes to desire, and he used often to pour Capillaire into his Glass of Port when it was his Custom to drink Wine which he has now wholly left off.' 3 In 1778 he stated: 'I now drink no wine, Sir. Early in life I drank wine: for many years I drank none. I then for some years drank a great deal.'4

Nevertheless, the full details of Johnson's pathological drinking cannot be determined, for the following reasons. Firstly, although he was at times refreshingly frank about his difficulties with alcohol, he could also be understandably secretive in this respect: 'When I drank wine, I scorned to drink it when in company. I have drunk many a bottle by myself; in the first place, because I had need of it to raise my spirits: in the second place, because I would have nobody to witness its effects upon me.'5 In addition, his biographers did not know him well during the years when his drinking was probably at its height (with the exception of Murphy, who first met Johnson in 1754); Hawkins' acquaintanceship goes back to Johnson's early years in London, but was not intimate; Boswell was introduced to him in 1763, and Mrs. Thrale in 1765; Garrick accompanied Johnson from Lichfield to the capital when both were young men, and the pair remained friends, but the actor's anecdotes are known only at second hand. Finally, Johnson on his death bed destroyed nearly all his private papers-their loss is tragic for many reasons, although the manuscripts he handed at the time to George Strahan record a struggle with alcohol from 1760 to 1767 , at first by attempts to drink less, and finally by abstinence. ${ }^{\circ}$

The Birmingham surgeon, Mr. Hector, told Boswell that as a young man Johnson 'loved to exhilarate himself with wine,' though Hector 'never knew him intoxicated but once."? According to Boswell, the first period of abstinence commenced around the time Johnson moved to London at the age of twenty-eight in $1737,{ }^{8}$ but Murphy's deduction is more attractive, that Johnson used to enjoy a bottle with the unstable poet Savage, and that 'his abstinence from wine and strong liquors began soon 


\section{J. S. Madden}

after the departure' of the latter from London in $1739 .^{\circ}$ We have Johnson's account that this initial spell of abstinence lasted several years, to be followed by the resumption of heavy drinking, but the dates are unascertainable. When Boswell became friendly with Johnson in 1763 the couple made a practice of drinking together so heartily that the Scotsman developed headaches. ${ }^{10}$ Boswell left for the Continent later that year, and when he returned in 1766 he found Johnson drinking only nonalcoholic beverages. ${ }^{11}$ With some exceptions, the second period of abstinence continued until 1781, when Boswell questioned Johnson about the latter's resumption of wine drinking, and was told: 'I drink it now sometimes, but not socially.'12 Boswell 'observed he poured a large quantity of it into a glass, and swallowed it greedily. Every thing about his character and manners was forcible and violent; there never was any moderation; many a day did he fast, many a year did he refrain from wine; but when he did eat, it was voraciously; when he did drink wine, it was copiously. He could practise abstinence, but not temperance.'12 Although Johnson records making punch for his servants and himself in March, $1782,{ }^{13}$ his drinking again appears to have abated, because in his final two years there was no suggestion that he drank for reasons other than those which, in the light of knowledge at that time, were medical indications. In June 1783, a stroke temporarily deprived him of speech: 'In order to rouse the vocal organs I took two drams. Wine has been celebrated for the production of eloquence.'14 His physicians (Heberden and Brocklesby) repeated the treatment, ${ }^{15}$ but it is likely that he again practised abstinence. During his final illness of December 1764, when pressed to take nourishment, he said, 'I will take anything but inebriating sustenance, ${ }^{16}$ although on the night before he succumbed to dropsy his attendants succeeded in giving him 'cyder and water.'17

Was Johnson an alcoholic? Certainly he had many of the features that develop in the course of alcoholism, notably a self-acknowledged difficulty in restricting his drinking to moderate amounts, solitary drinking, guilt concerning his alcohol intake, and periods of abstention. That he was on only two occasions reported to be intoxicated ${ }^{78}{ }^{18}$ does not decry the diagnosis of alcoholism, partly because of his admission that 'I used to slink home when I had drunk too much', ${ }^{19}$ and partly because obvious intoxication is not a necessary feature of the disease, some alcoholics retaining the ability to prevent intoxication..$^{20}$ On the other hand, if Johnson were a fully developed alcoholic, we would expect evidence that his drinking had impaired his marriage and his career; there was no sign of this nature regarding his marriage, while during the decade prior to meeting Boswell, when his drinking was presumably at its heaviest, he strengthened his literary reputation (notably by the Dictionary published in 1755 and by Rasselas written in 1759) to the extent that he was granted a State pension in 1762. Basically the question hinges on the definition of alcoholism, but loss of control over the amount consumed if alcohol is drank at all, is generally accepted to be a necessary feature of the disease; by this concept Johnson may not be viewed as an alcoholic, despite his statements that he was unable to drink moderately. During his second period of so-called abstinence there were several incidents when he drank a limited quantity of alcohol. He consumed 'one glass of wine to the health of Sir Joshua Reynolds'21 when the latter was knighted in 1769; during the tour of Scotland in 1773, Johnson was on one occasion 'prevailed with to 


\section{Samuel Johnson's Alcohol Problem}

drink a little brandy when he was going to bed', 2 and the following month sampled whisky, with the remark: 'Come, let me know what it is that makes a Scotchman happy!'22 In 1779 he was persuaded to drink one glass of claret, which confirmed his recollection of it as: 'Poor stuff! No, Sir, claret is the liquor for boys; port for men; but he who aspires to be a hero (smiling) must drink brandy . . . brandy will do soonest for a man what drinking can do for him.'23 The mystery of the orange peel, which he regularly gathered and cut for a purpose that baffled Boswell, ${ }^{24}$ is explained by his drinking it in a glass of hot port as 'a very probable remedy for indigestion and lubricity of the bowels.'25

Whatever definition is attached to alcoholism, it can be agreed that Johnson was, at the least, a prodromal alcoholic. What were the conditions that determined his pathological drinking? Since socio-economic factors are the most influential in affecting the incidence of excessive drinking, attention must first be given to these. Hogarth and Fielding have portrayed the epidemic of gin drinking in London that began in 1690; this reached its maximum in the seventeen forties and was subdued by severe taxation until it recurred throughout the country with the Industrial

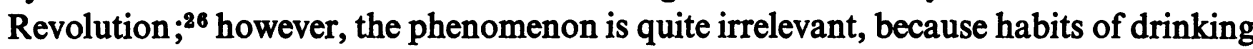
(whether of social or of excessive consumption) vary with social class, and Johnson mixed with the class whose taste was for wine. Historians agree that among the gentry of his time inordinate wine drinking was prevalent; it would be fitting to have objective data to support their belief but it is not possible to provide this. There is no reliable information from the eighteenth century of the morbidity and mortality due to alcoholism; $;^{27}$ an estimate from the official figures of wine importation points to a higher level per head than consumption in succeeding times, but the difference is not great (Appendix). There was a flourishing trade in smuggling, concerning which government statistics provide no information, but it is impossible to assess the extent that this romantic pursuit fostered heavy wine drinking. We are obliged to rely on anecdotes of a general and individual nature. At the beginning of the century there was a 'haze of drinking that followed the meal, after the ladies had left the table' ${ }^{28}$ in the Georgian period 'hard drinking among the richer classes was prevalent'. ${ }^{29}$ The most learned scholar of the era-Bentley-succumbed to wine; ${ }^{30}$ Walpole as Prime Minister 'drank steadily and told the broadest of stories over the bottle';31 Johnson in his Lives of the Poets describes the heavy drinking of Parnell, Addison and Collins, while his own problem with alcohol was less severe than Boswell's. ${ }^{22}$

It may at any rate be concluded that Johnson's vulnerability to alcohol was encouraged by inclinations in the society of which he was a member. Morbid drinking has a familial tendency, so it is appropriate to look next for alcoholic trends in his relatives. Apart from his parents, we know little about his kindred, and that little reveals no alcoholism. It is alleged that his cousin, the profligate Parson Ford, is portrayed next to the punch bowl in Hogarth's 'Modern Midnight Conversation', ${ }^{33}$ and Johnson wrote of his deceased brother, Nathaniel: 'His memory might probably continue for some time in some favourite alehouse'. ${ }^{34}$ Neither instance furnishes grounds for diagnosing alcoholism.

Regarding emotional problems within Johnson's constitution that led him to find relief in alcohol there is a wealth of evidence. He said, 'I inherited a vile melancholy 


\title{
J. S. Madden
}

from my father'. ${ }^{85}$ In 1773 he wrote: 'I can now look back upon threescore and four years, in which little has been done, and little has been enjoyed, a life diversified by misery, spent part in the sluggishness of penury, and part under the violence of pain, in gloomy discontent, or importunate distress' ${ }^{36}$ Perhaps Johnson's depressive frame of mind is best conveyed by the remark of his fictional philosopher in Rasselas: 'Human life is everywhere a state, in which much is to be endured, and little to be enjoyed'. At times his depression deepened: 'Melancholy has had in me its paroxysms and remissions' ${ }^{37}$ one of the exacerbations, in about 1764 , may have been the illness which led to his second period of virtual abstinence, and has been described at second hand by Boswell:

\begin{abstract}
About this time he was afflicted with a very severe return of the hypochondriack disorder, which was ever lurking about him. He was so ill, as, notwithstanding his remarkable love of company, to be entirely averse to society, the most fatal symptom of that malady. Dr. Adams told me, that, as an old friend he was admitted to visit him, and that he found him in a deplorable state, sighing, groaning, talking to himself, and restlessly walking from room to room. He then used this emphatical expression of the misery which he felt: 'I would consent to have a limb amputated to recover my spirits'.88
\end{abstract}

The description suggests an endogenous phase, but it cannot be held that Johnson was liable to attacks of endogenous depression, if this illness is regarded as occurring in persons who, between attacks, enjoy sound mental health. Apart from a permanent depressive outlook of a neurotic nature, there were other psychiatric features, such as tics: 'Cruel infirmities to which he is subject; for he has almost perpetual convulsive movements, either of his hands, lips, feet, or knees, and sometimes all together. ${ }^{39}$ These should be distinguished from his compulsions; the latter were generally ignored by his biographers, though Miss Frances Reynolds left a full and vivid account:

\begin{abstract}
Sometimes he would with great earnestness place his feet in a particular position, sometimes making his heels to touch, sometimes his toes, as if he was endeavouring to form a triangle, at least the two sides of one, and after having finish'd he would beat his sides, or the skirts of his coat, repeatedly with his hands, as if for joy that he had done his duty, and what was very extraordinary, after he had quitted the place, particularly at the entrance of a door, he would return to the same spot, evidently, I thought, from a scruple of conscience, and perform it all over again. ${ }^{40}$
\end{abstract}

She also noted an occasion when, in her company at Twickenham meadows, his gestures were so extraordinary 'that men, women, and children gathered round him, laughing'.41

Allied in nature to the compulsions were obsessional doubts: 'Scruples distract me'. ${ }^{42}$ Other neurotic difficulties included insomnia, fear of insanity, ${ }^{48}$ and a morbid dread of death based on uneasiness about sexual behaviour as a young $\operatorname{man}^{44}$ and on a conviction about the sternness of the Divine Judge. ${ }^{45}$ Johnson was aware that alcohol afforded 'seducing Relief' to solitude, ${ }^{46}$ and the loneliness of which he complained was partly determined by psychological reasons. His melancholy, grotesque appearance, mannerisms and compulsions, as well as an inclination 'to treat mankind with asperity and contempt', ${ }^{47}$ gave him a sense of isolation with a defensive pride that led to his arguments for victory-arguments that have delighted succeeding 


\section{Samuel Johnson's Alcohol Problem}

generations, but that had an urgency deplored by a contempory observer: ' $\mathrm{He}$ fought on every occasion as if his whole reputation depended upon the victory of the minute, and he fought with all the weapons. If he was foiled in argument he had recourse to abuse and rudeness'. ${ }^{48}$

In part, no doubt, Johnson's solitude was also due to the death of his wife when he was forty-two, leaving him childless, but although his grief for her appears to have been sincere and lasting ${ }^{49}$ there is evidence that his spouse brought discontent to him. Mrs. Thrale on this point quoted Levett (a companion of Johnson who practised medicine unofficially but conscientiously) as saying: 'She was always drunk and reading Romances in her Bed, where She killed herself by taking Opium.' ${ }^{50}$ It is not uncommon to find a problem drinker married to a person with the same condition, while the direction of age difference between the couple (she was older than Johnson by twenty-one years) is also fairly frequently encountered in the marriages of male alcoholics. Alliances of the latter nature satisfy immature dependency needs of the husbands-needs that also seek gratification from alcohol;51 it is reasonable to suggest that Johnson's marriage to a maternal figure was similarly determined (in addition to the age disparity she was a widowed mother when he married her). The line of thought could be pursued further, though more tentatively. As an adult Johnson expressed scant regard for his parents; a prospective study of boys who later became alcoholic has revealed that many of the subjects had felt unsure of their mother's affection and had lacked the type of father whom they could esteem. ${ }^{52}$ We cannot be sure, however, that Johnson's childhood relationship with his mother was defective, despite the hints offered by his choice of a mother surrogate as spouse and by his problem with alcohol; in any case all attempts to chart a comprehensive psychopathology for an individual who lived two centuries ago are likely to be naive. Johnson must have been affected by the 'gloomy wretchedness' of his father, though whether for the most part by genetic or by environmental means is a question which, at the present stage of development in psychiatry, would evoke too many prejudices to be satisfactorily answered.

Johnson's attitudes to social and excessive drinking have been well recorded. With his usual sympathy for the poor, he justified giving money to beggars even though they might spend it only on gin and tobacco: 'Why should every body else find Pleasure necessary to their Existence and deny the poor every possible Avenue to it?' ${ }^{53} \mathrm{He}$ could also be tolerant 'to those who indulged in occasional excess in wine, ${ }^{54}$ and in a famous phrase asserted that 'a tavern-chair was the throne of human felicity. ${ }^{55}$ On the other hand, 'he often enlarged upon the evil of intoxication, ${ }^{53}$ was self-righteously condemnatory towards the excessive drinking of Addison and Charles Congreve, ${ }^{56}$ scoffed at Sir Joshua Reynolds for adopting the social convention of wine drinking, ${ }^{57}$ and maintained that alcohol improved neither conversation nor benevolence. ${ }^{58}$ In summary, his views on alcohol were ambivalent, which is interesting in view of a recent hypothesis that ambivalence in this respect is a contributory cause of alcoholism. ${ }^{59}$

Before concluding the consideration of factors which may have led to Johnson's problem with alcohol it should be noted that he was exposed to other stresses that were not psychiatric in origin. They included the poverty of his early years, a face 


\section{J. S. Madden}

scarred by scrofula, regret over his lack of training in a profession, deafness, shortsightedness, gout, and 'asthma' in old age. ${ }^{60}$

How was he enabled, in large measure, to check his inordinate drinking and prevent the development of the worst ravages of alcoholism? The explanation must primarily lie in the positive aspects of his personality. Although it is not established beyond contention that high intelligence improves the prognosis for pathological drinkers, he himself had the impression (which may well prove to be correct) that intellectual resources were of assistance 'to forego the pleasures of wine'. ${ }^{61}$ Johnson's intellectual powers were immense, while the extent to which he developed and utilised them indicates a considerable degree of emotional stability. Born into an era dominated by social distinctions and by patronage he worked his way unaided from a humble background to the eminence of a literary monarch with whom noblemen, statesmen and the King were glad to converse. As additional evidence for his assets of temperament, there are his writings and sayings; they reveal that he had endurance, a common sense approach to many of life's problems, and a saving sense of humour.

Three other factors helped him in his struggle against alcohol, although paradoxically the first certainly, and the others possibly, had aggravated his drinking. Alcohol affords relief from obsessions, but the possession of obsessional features is associated with qualities of conscientiousness and self-discipline that add steadiness to the individual. Johnson felt constantly menaced by insanity, yet the fear eventually contributed to his abstinence: 'For (said he) what ferments the spirits may also derange the intellects, and the means employed to counteract dejection may hasten the approach of madness. Even fixed, substantial melancholy is preferable to a state in which we can neither amend the future, nor solicit mercy for the past. ${ }^{62}$ His concern to amend the future was partly based on an over-fearful approach to religion, but he was able to use spiritual assistance in his alcohol difficulties."

The numerous therapeutic facilities that exist at the present time for patients with drinking problems were not available to Johnson. His lonely, largely successful, combat with alcohol is an encouragement to problem drinkers and to their doctors; it illustrates how alcohol can threaten the most talented type of person, and it affords one more ground for revering this great and lovable man.

\section{APPENDIX}

An estimate of wine importation per head in the eighteenth century, compared with wine consumption in some later years.

Because of fluctuations from year to year, the eighteenth century calculations are quinquennial. The official import totals are provided by Schumpeper, E. B., English Overseas Trade Statistics 1697-1808, Oxford, Clarendon Press, 1960; her figures for the end of the century include Scotland. Population size was unknown before the first census of 1801; following Williams, B. (The Whig Supremacy, 1714-1760, 2nd. 


\section{Samuel Johnson's Alcohol Problem}

ed., Oxford, Clarendon Press, 1962, p.124), the population of England and Wales is assumed at six million for the beginning of the century, and seven million in the middle; for the final quinquennium the population of the three countries is assumed to be identical with the 1801 census figure. Port formed the bulk of wine imports, though this beverage was not fortified before 1830 .

The data subsequent to 1800 are taken from Moynihan, N. H., 'The treatment of alcoholism in general practice', in Selected Papers presented at the 10th European Institute on the Prevention and Treatment of Alcoholism, Lausanne, International Bureau against Alcoholism, 1964, p. 78.

Official imports of wine per head

\begin{tabular}{|c|c|l|}
\hline Year & Wine in gallons & \\
\cline { 1 - 2 } $1700-1704$ & 0.74 & \multirow{2}{*}{ England and Wales } \\
$1750-1754$ & 0.56 & England and Wales \\
$1796-1800$ & 0.58 & England, Wales and Scotland \\
\hline
\end{tabular}

Consumption of wine per head

\begin{tabular}{|c|c|c|}
\hline Year & Wine in gallons & \\
\hline 1852 & 0.23 & \multirow{2}{*}{ United Kingdom } \\
1900 & 0.42 & United Kingdom \\
1940 & 0.45 & United Kingdom \\
1961 & 0.53 & United Kingdom \\
\hline
\end{tabular}




\section{J. S. Madden}

\section{NOTES AND BIBLIOGRAPHY}

1. HiLL, G. B., Johnsonian Miscellanies, Oxford, Clarendon Press, 1897, vol. II, p. 197.

2. Boswell, J., Journal of a Tour to the Hebrides with Samuel Johnson. LL.D., 1786, ed. by R. W. Chapman, London, Oxford University Press, 1961, p. 302.

3. Thrale, H. L., Thraliana: The Diary of Mrs. Hester Lynch Thrale (later Mrs. Piozzi), 1776-1809, ed. by K. C. Balderston, 2nd ed., Oxford, Clarendon Press, 1951, p. 186. Capillaire is an infusion of orange.

4. Boswell, J., The Life of Samuel Johnson, LL.D., 1791, Everyman Edition, London, J. M. Dent \& Sons, 1946, vol. II, p.219.

5. Ibid., vol. II, p. 30.

6. HIIL, op. cit., vol. I, pp. $25,28,30,38,43,44$.

7. BosWell, Life, op. cit., vol. I, p. 48.

8. BosWell, Life, op. cit., vol. I, pp. 55-56.

9. HILL, op. cit., vol. I, p. 376.

10. Boswell, Life, op. cit., vol. II, p. 271.

11. Ibid., vol. I, p. 315 .

12. Ibid., vol. II, p. 367

13. HIIL, op. cit., vol. I, p. 103.

14. Johnson, S., The Letters of Samuel Johnson, ed. by R. W. Chapman, London, Oxford University Press, 1952, vol. III, letter 850.

15. Ibid., vol. III, letter 851 .

16. Boswell, Life, op. cit., vol. II, p. 608.

17. Ibid., vol. II, p. 610 .

18. HIIL, op. cit., vol. II, p. 321.

19. Boswell, Life, op. cit., vol. II, p. 276.

20. Jellinex, E. M., The Disease Concept of Alcoholism, New Haven, College and University Press, 1960, section III. 1.2., Cf., for instance, Johnson's description of Charles Congreve's alcoholism: ' . . . not that he gets drunk, for he is a very pious man, but he is always muddy. He confesses to one bottle of port every day, and he probably drinks more' (Boswell, Life, op. cit., vol. I, p. 626).

21. HIIL, op. cit., vol. II, p. 322.

22. Boswell, Journal of a Tour to the Hebrides, op. cit., p. 393.

23. Boswell, Life op. cit., vol. II, pp. 270-271.

24. BosWell, Life, op. cit. vol. I, pp. 536-537.

25. JoHnson, Letters, op. cit., vol. I, letter 79.

26. Trevelyan, G. M., History of England, London, Longmans, Green \& Co., 1945, p. 525.

27. The term 'delirium tremens' was not coined by Thomas Sutton until 1813 (CuTshaLL, B. J., 'The Saunders-Sutton syndrome: an analysis of delirium tremens', Quart. J. Stud. Alc., 1965, 26, 423-448). Laënnec, when he initially proposed the name 'cirrhosis' in 1819, did not mention alcohol as a cause (LeIBOwrtz, J. O., 'Studies in the history of alcoholism-I', Brit. J. Addict., 1965, 61, 129-134).

28. JARRETT, D., Britain 1688-1815, London, Longmans, Green \& Co., 1965, p. 60.

29. Richardson, A. E., Georgian England, London, B. T. Batsford, 1931, p. 28.

30. PoPe, A., The Dunciad, Book IV.

'Where Bentley late tempestuous wont to sport

In troubled waters, but now sleeps in port.'

31. TreVelyan, op. cit., p. 534.

32. Pearson, H., Johnson and Boswell, London, William Heinemann, 1958, p. 381.

33. BosWell, Life, op. cit., vol. II, p. 249.

34. Johnson, Letters, op. cit., vol. II, letter 710. It has been suggested that Nathaniel 'possibly died from his own hand' (KRUTCH, J. W., Samuel Johnson, London, Cassell \& Co., 1948, p. 44).

35. Boswell, Journal of a Tour to the Hebrides, op. cit., p. 302. 


\section{Samuel Johnson's Alcohol Problem}

36. JoHnson, Letters, op. cit., vol. I, letter 326.

37. HILL, op. cit., vol. I, p. 74.

38. Boswell, Life, op. cit., vol. I, p. 300.

39. BuRney, F., The Diary of Fanney Burney, ed. by L. Gibbs, Everyman Edition, London, J. M. Dent \& Sons, 1950, p.10.

40. HIIL, op. cit., vol. II, p. 274.

41. Ibid., vol. II, p. 297.

42. Ibid., vol. I, p. 38. On this page Hill gives a list of references to Johnson and scruples.

43. THRALE, op. cit., pp. 384-385.

44. BOSWELl, Life, op. cit., vol. II, pp. 595-598.

45. Seward, A., The Letters of Anna Seward, ed. by A. Constable, Edinburgh, Constable \& Co., 1811, vol. II, p. 104. Johnson 'worshipped God as Indians worship the devil'.

46. Thrale, op. cit., p. 180.

47. HIIL, op. cit., vol. II, p. 259.

48. Ibid., vol. II, p. 228.

49. Boswell, Life, op. cit., vol. I, pp. 139-140.

50. Thrale, op. cit., p. 178. H. Pearson (Johnson and Boswell, op. cit., p. 42) postulates that Johnson spent so much time in taverns at one period because of the marital infelicity.

51. Jones, H., Alcoholic Addiction, London, Tavistock Publications, 1963, pp. 53-55.

52. MCCORD, W. and MCCORD, J., Origins of Alcoholism, London, Tavistock Publications, 1960.

53. Thrale, op. cit., p. 185.

54. Boswell, Life, op. cit., vol. I, p. 611.

55. HinL, op. cit., vol. II, p. 91.

56. JoHnson, Letters, op. cit., vol. II, letter 460.

57. Ibid., vol. II, letter 374 .

58. Boswell, Life, op. cit., vol. II, p. 29.

59. Chafetz, M. E., and Demone, H. W., Alcoholism and Society, New York, Oxford University Press, 1962, p. 75. The hypothesis is largely derived from studies of primitive cultures, and is not necessarily relevant to Georgian England.

60. Johnson's fatal dropsy was presumably from right ventricular failure, but his 'asthma' was at first due to emphysema (BraIN, R., Some Reflections on Genius, London, Pitman Medical Publishing Co., 1960, p. 100.)

61. Boswell, Life, op. cit., vol. I, p. 395.

62. HILL, op. cit., vol. I, p. 322. 